\title{
ISLAMIC EDUCATION IN THE CONTEXT OF INDONESIA NATIONAL EDUCATION
}

\section{Muchtarom}

Universitas Padjajaran Bandung Jl. Raya Bandung-Sumedang KM 2140600

Email: muchtarom_2012@yahoo.co.id

\begin{abstract}
Islamic Religion Education has been part of National Education System, however, its existence and contribution are less significant especially in empowering the nation. In fact, Islamic education has great potential in building character. This paper aims at identifiying and analyzing the efforts on Islamic Religion Education development in National Education System. This study used descriptive analysis method through literature review as secondary data. The result shows that Islamic Religion Education development in National Education System attempted to eliminate dycothom between general education and religion education independently. Otherwise, it must have a collaboration with other education. In sum, Islamic Religion Education is not only legitimized in a whole as a part of National Education System but also it requires a curriculum change that collaborate Islamic Religion Education System with other subjects.
\end{abstract}

Keywords: Education development, Islamic Religion Education, National Education System

ABSTRAK

Pendidikan Agama Islam merupakan bagian dari Sistem Pendidikan Nasional Indonesia, namun keberadaan dan kontribusinya kurang signifikan terutama dalam memberdayakan bangsa. Padahal, Pendidikan Agama Islam berpotensi besar dalam membangun karakter. Tulisan ini bertujuan untuk mengetahui dan menganalisis upaya pengembangan Pendidikan Agama Islam dalam Sistem Pendidikan Nasional. Metode penelitian yang digunakan berupa analisis deskriptif dengan melakukan kajian pustaka sebagai data sekunder. Hasil analisis ini dapat disimpulkan bahwa upaya pengembangan Pendidikan Agama Islam dalam Sistem Pendidikan Nasional harus menghapuskan dikotomi ilmu umum dan ilmu agama yang berdiri sendiri,dan berubah menjadi keterpaduan berupa kolaborasi dengan pendidikan lainnya. Pendidikan AgamaIslam tidak hanya dilegitimasi secara penuh sebagai bagian dari Sistem Pendidikan Nasional, tetapi Pendidikan Agama Islam memerlukan perubahan kurikulum yang menggabungkan Sistem Pendidikan Agama Islam dengan ilmu lainnya.

Kata Kunci: Pengembangan Pendidikan, Pendidikan Agama Islam, Sistem Pendidikan Nasional 


\section{INTRODUCTION}

Education objective becomes the most important thing in education including in Islamic Religion Education. An unclear formulation in education objective leads to the vague learning process and uncertain target. Worstly, it can possibly cause wrong way which is not as it is expected. In the context of National education, basically, Islamic Religion Education is directed to the objective of National Education, that is, to make the citizen smart and to develop Indonesian's potential in a whole to be a man that has imân and taqwa to God Almighty and has a precious character that acquires knowledge and skill, gets healthiness both physical and spritual, becomes independent and strong personality as well as responsible person for society and nation" (UU RI No. 20 Thn. 2003 in Grafika, 2007: 5).

The objective that has been formulated above in the form of Acts does not always run well without any obstacles. In fact, in its implementation, there are often inappropriate and dissatisfied part between education output and its objective especially the aim to form precious character. This condition can be reflected in some immoral cases occured in our society such as corruption, sexual abusement, family harrashment and other criminal actions. Such cases show that the objective of Islamic Religion Education has not been achieved yet perfectly. However, most of them who did corruption had learn or got Islamic Religion Education both in their formal school and university. Basically, there is nothing wrong with the performance of Islamic Religion Education in Indonesia since it contains good moral values. The deficient of its implementation is not due to the religion which is absolutely right but it might be caused by human error.

Therefore, this paper aims to identify the main problems of Islamic Religion Education in the context of National Education System, to anlayze it and give solutions theoretically, methodoligically, and practically. This study used descriptive qualitative which put forwards analysis of literature study related to the existence of Islamic Religion Education in Indonesia.

\section{ANALYSIS}

Islamic Education in Indonesia has had a long history in the archipelago. It has in its various iterations, served Muslims communities since the early coming of Islam to the area. According to Saefuddin, Islamic education in Indonesia started from a forum of Islamic instructions (pengajian) held by the carrier and preacher of Islam in citizens' houses mosques. The forum was then consolidated into pesantren and madrasah (Saefuddin, 1995: 237).

All activities has their own goal (teleology). Objective is individual or group's target achievement in doing an activity, including Islamic Religion Education. Zakiah Darajat states that objective is something that is expected to be achieved after finishing an activity. Thus, the objective of Islmic Religion 
Education is an individual or group's target achievement in conducting Islamic Religion Education (Ihsan dan Fuad, 2007:68).

To formulate the objective of education becomes an abolute requirement to define the education itself. At least, its formulation must contain a basic concept or knowledge of human, nature and God. According to Hitami (2004: 34), the obejctive of education cannot be separated from human life's objective which are influenced by various cultures, point of views and desires. Sanaky (2003: 5) mentionsthat the objective of Islamic education is based on vision and mission of Islam, i.e., "rahmatan lil 'âlamîn".

In Islamic studies, human being is Allah SWT's creature which has duty in the world to do praying and to be pious servant for Allah SWT. Thus, the general aim of Islamic Religion Education is to form human being as Allah's servant that prays obediently. In the context of Islamic Religion Education in Indonesia, education must attempt to make all citiziens bent down to Allah SWT. In other words, they become obedient and diligent in praying to Allah and in devoting to their nation. Nevertheless, the final objective of Islamic Religion Education in Indonesia attempts to realize moslems which have imân and taqwa as well as knowledegable that are able to be Allah's servant and fateful in all aspects of life (including to live as citizen in the country and nation) to reach happiness in after life (Uhbiati dan Ahmadi, 1995: 65).

According to al-Abrasyi (2006:138), the main objectives of Islamic Religion Education are to do: a) akblâq training; b) preparation for students to live in the world and after life; c) mastery in science and technology; d) skill improvement in working world and society interaction. Thus, the nature of Islamic Religion Education in Indonesia, basically, carries out the process of humanity and being humanity for Indonesian people. Actually, humanity and being humanity have meaning to create and to form positive characters for individual that behave normally and think logically as Allah SW'T's servant. This is due to be an effort or a process to be an intact human being. This condition shows that ideologically Islamic Religion Education in Indonesia attempts to make students be able to do their main duty and function as human beings. In short, it tries to bring about their akblâq.

The aims of Islamic Religion Education implementation in Indonesia obviously can not be separated from education principals based on al-Qur'an and hadits values. At least, there are five principles for Islamic Religion Education implementation, among others:

1. Integration principles. This principle emphasizes the relationship between the world and after life. Islamic Religion Education attempts to balance happiness in the world and after life through the development general and religious knowledge.

2. Balancing principle. This principle emerges as the result of integration principle. Its balancing includes proportional elements between spiritual and physical, between pure and applied science, between 
theory and practice, and proportional value among aqîdah, syar'i, and akblâq.

3. Similarity and liberation principle. This principle is developed from taubîd value, i.e., Allah SWT is the one and only. Every individual or students, in fact, all human beings are created by the same creator, Allah SW'T and they are equal in front of Him. The difference lays on the elements of creation and taqwa that have potential to strengthen the unity of universe. Islamic education is one of efforts to free human beings from shackle of world's desire into a clear and precious taubid value. Human beings thorugh all forms of education are expected to be released from idiocy, proverty, obstinancy, and their bayawâniat an-nafs.

4. Continuity principle (istiqâmah). It means long live education principle. In Islamic studies, learning becomes an obligation that will not be ended until death. The command to read content of al-Qur'ân is an order that has no time limit. By learning knowledge continually, it is expected that it will come an existencial awarness in themselves, their environment, and their God.

5. Benefit and superiority principle. This principle is obtained from taubid spirit which has been planted and developed in individual's moral and akblâq systems so that it will form a holly qalb and authentic faith, that protects him or her form impurity soul. This will make him or her have a fight and struggle to defend the truth and to get benefit from life. Nevertheless, tauhîd value can only be felt if it has been manifested in each movement of human's life to reach benefits and superiority of universe (Roqib, 2009: 32-33).

Those quotations above show that principle of Islamic Religion Education is identical with every moslem's life principle, i.e., imân, taqwa, precious akhlâq, and strong character. Those principles are, then, specified through some indicators so that it is easily applied and evaluated. Besides, they must be elaborated into some conceptual and operational steps to be applied easier in any forms of education in family, school, and society. In other words, Islamic Religion Education obviously can be a spirit for other general education implementations.

Since the main source of Islamic Religion Education (IRE) is al-Qur'an and hadits, its basic education implementation refers to aqîdah, religious service, and akblâq. In aqîdah context, IRE is developed based on understanding of faith about Allah SWT's existence. In religious service context, IRE must be constructed based on an effort to convince individual about Allah SWT's existence. In specific, IRE attempts to make worship to Allah SWT as the only process to do all aspects of life both physical and spiritual, both in individual life as Allah's servant and in society life as social interaction or even in universe as caliph on Earth. Therefore, to gain a perfect objective of IRE for this life, one of its basic education implementations refers to religious service both mahdlah and 
ghairu mabdlah. In relation to akblaq, at least IRE concerns to the process of reforming students to be human beings that have good moral, attitude, positive manner and behavior. A society will not be developed if their citizens do not have praised akblâq that can guide human to be advance in glorious civilization of life. Moreover, akblâq guidance is the soul of Islamic education. The achievement for precious akßhla $q$ becomes the main target of Islamic Religion Education (Solihin dan Anwar, 2005: 17).

In term of law context, IRE always be based on three elements: al-Qur'ân, badîts and ijtibâd. Al-Nahlawi (199: 41) suggests that al-Qur'an and badits are the main source and basic of law for Islamic Religion Education implementation. Rasul and his followers, as society educators, really respect al-Qur'ân. 'Aisyah attested that, actually, Rasul's akblâq is al-Qur'ân. Besides, hadîts is also the basic element of Islamic Religion Education since it explains. Yaljan (1992: 40) states that the basic implementation or IRE consists of al-Qur'an and sunnab extended to ijma', qiyâs, masâlih al-mursalah, shadzৃdzu al-dzâri'ah, 'urf dan istibsân. According to Ali (2005: 35), there are six basic elements of IRE implementation, among others al-Qur'ân, hadits, qaul al-shahâbat, masâlih al-mursalab, 'urf as well as all thoughts as the result of ijtibâd from intellectual moslem.

The Pillars of Islamic Education Seen from its stakeholders, at least five pillars of Islamic education in Indonesia can be listed: Pesantren, Madrasah, Islamic schools under Muslim organizations, Islamic Integrated Schools, and Majelis Taklim. Before the twentieth century, pesantren were the only formal institutions of Islamic education in the archipelago, mainly on Java Island (Lukens-Bull, 2004: 299).

At least, IRE impelementation refers to six Islamic precepts, as follows:

1. Universality of Islamic precept. This principle undoubtedly shows that Islamic Religion Education must be universal between physical and spiritual, individual and society, and world and after life. Through this principle, IRE must open, develop, and educate all aspects related to personality, skills, and human potential by expanding all aspects of life in society and improving culture, social, economy and politic conditions. In addition, it can overcome some problems faced by society nowadays and prepare them to challenge the future demand. In short, IRE covers all individual and sociaty developments.

2. Balancing. IRE actualizes a balance between growth aspects both in individual and society. This means that IRE also attempts to realize a balance between past culture, recent demand, and future needs without specializing one of them. IRE not only highlights past glory without ignoring the problems in moslem society recently but also fulfils all demands in current social and culture development by considering all future effects.

3. Clarity. IRE as clear Islamic precept has a clear concepts including in methodology, curriculum, system and other aspects in education. 
Clarity will influence the operational Islamic Education to achieve its objective.

4. Harmony. IRE is organically organized among its parts without any contradiction. Since it is based on Islamic precept, IRE must perform based on Allah's will. It is different from other education system that prioritized the obkective of education without considering the process. In IRE, the objective must achieve based on Islamic syarîa

5. Realistic and applicable. IRE performs in a clear and realistic frame of society life. However, IRE emphasizes on Islamic idealism that sometimes is missunderstood by the impelementer of IRE. As the result, Islamic Education idealism is viewed as institution that prioritized ukhrawi values and does not concern the reality. Clearly, IRE performs based on the development in the society and preservers Islamic values as its principle.

6. Dynamic and responsive toward alteration. IRE is not frozen in its objective, curriculum, and method but it always renews and develops as well gives postive response toward the needs and development era. Besides, it responds to individual and society interest.

(Basri, 2009, 129-130).

Therefore, it is clear that IRE does not close itself to the development in society including science and technology development. Nevertheless, IRE does not blend on the development againsy Islamic syarîa

IRE's role is to give contribution to the effort of potential development of its student as next generation who not only develops in intellectual field but also can realize their existence as insân kâmil based on his spiritual potential and skills. Thus, with his potential, he can color his life and his future to achieve happiness in the world and after life. In addition, there are some IRE functions, as follows: 1) to achieve the objective; 2) to direct the objective; 3) As the main point to achieve other objectives, i.e., the new objectives or extansion objective from the previous one; 4) to give value on the efforts; 5) to provide criteria to evaluate education process; 6) to provide facilitation in order to make the education process run well (al-Rasyid and Nizar, 2005: 32).

IRE has its own characteristic if it is compared with other education in general. If general education does not have specific element, IRE has its own rule, i.e, refering to al-Qur'ân and hadits. Furthermore, there is a special thing in IRE, i.e. charismatic kiai, that is not owned by other educators generally. Following are the characteristics of IRE:

1. Rabbaniyyah, all aspects is based on rabbaniyah value, elaborated on Kitâbullâh and Sunnat ar-Rasûl;

2. Syâmilah, education is constructed by paying attention on all aspects of life including mind, body and spirit as well as relationship between individual and society, nature and al- Khâliq, without separation; 
3. Mutakamilah, education is not limited on particular place. It can be held at school, mosque, home, on the street, in the garden, in battlefield or even in market;

4. Marbaliyah, all nature occurs in a phase as well as human grows physically and mentally. Thus, education must be build in a phase based on human matureness development;

5. Murunah, the education application is based on situation and condition which cover object and subject of education to optimalize the result;

6. Istimrâriyah, education process is always continuity. Every individual learns in all his life (Long Live Education);

7. Tanmawiyah, it gives a chance to renew delivery method and style according to the science innovation and development as long as it still runs on Islamic principles;

8. Fardiyah, Learning knowledge is a compulsory for every individual in Islam. As the result, it involves all parties to prepare all education facilities as well as possible;

9. Tathbiqiyah, education is practical which means every achieved knowledge must be oriented to productivity;

10. Hurriyah, education is based on freedom. Islam does not force to learn what and how. Every individual is free to learn and anyknowledge and its limitation;

11.Infitâh, education is based on openess. Every moslem absorbs knowledge from any sources and can benefit turâts (useful legacy from the past human civilization);

12. Maslahah, education is formed to give benefit for ummah, later, it can gives contribution to education, prosperity, glory, and civilization. Thus, IRE is oriented to benefit value for ummah.

\section{IRE Existence in National Education System}

All nations in the world have their ownnational system. National education is usually colored their own values and cultures which grow together with all live movement of a nation. National education system must be organized based on Indonesia's value and culture as a cristalization from value of Indonesia life. The implementation of national education is arranged according to education needs in Indonesia geographically, demographically, historically and culturally as the typical things from Indonesia.

There is a strong relationship between education and culture. Both of them are connected to values. Thus, education cannot be separated from culture and it can only be implemented in a society. Education is a culturization process of society. Basically, culture has three important aspects, culture as order of life, culture as a process, culture with certain vision and goal. Inother words, education process will not occur without culture and society. 
Thus, education cannot be separated from society life around it. John Dewey (1916: 296 ) states: "Can we connect this" New Education "with the general march of events? If we can, it will lose its isolated character, it will cease to be an affair which proceeds only from the over genius mind of pedagogues dealing with particular pupils". The educators and anthropologists agree that culture is the basic element formed human's personality. Based on culture, it can form individual, society and nation identity. In the recent world, someone can be influence by global culture. Actually, modern human live globally, i.e., in a realistic world without limitation and with cyber world of information and technology in advance. Culture is not static but it is a process. Thus, culture is always in a transformation process. Culture without transformation through education process refers to died culture.

Since 2003, Indonesa has new Acts of National Education System. The decision of the Acts was based on consideration that Acts No. 2 Year 1989 regarding National Education System was no longer suitable and it needed to be changed or revised so that it is appropriate with the alteration of Undang-undang Dasar Republik Indonesia Tabun 1945.

In Acts of National Education System, education means as conscious and planned efforts to realize learning process and atmosphere so that students actively develop their potential to own the strength on spiritual, self control, skill needs for themselves, society, nation and country. Meanwhile, the objective of national education is to develop students' potential to be human beings that have imân and taqwa to the only one God, precious akblâq, healthiness, well knowledge, skillful, creativity, independent, and democratic and responsible citizen.

In addition, national education system means all education components related one to another cohesively to achieve the objective of national education. There was a case that someone continued his study for economy reason and it is considered to be an investation, i.e., title is gained without considering his own quality. Title becomes the main target to be realized in order to get back his financial tuitition and get the profit from it. This kind of education objective cannot make individuals to have precious akhlâq although they achieve a higher degree.

There are many high educated moslems but they are not good moslems yet in the reality. It can be denied that there is still a gap between the high title and lower moral and akhlâq in life. Thus, the Islamic Religion Education does not mean anything to his life and it cannot be enjoyed. In another case, there are many politicians, businessmen, and educators who admit that they are moslems and get high title as intellectual but in the reality, they are involved in some corruption, sexual abusement, misuse authority, family harrasment, and any deviant objective from Islamic Education. Those cases bring to the urgent development for Islamic Religion Education. 


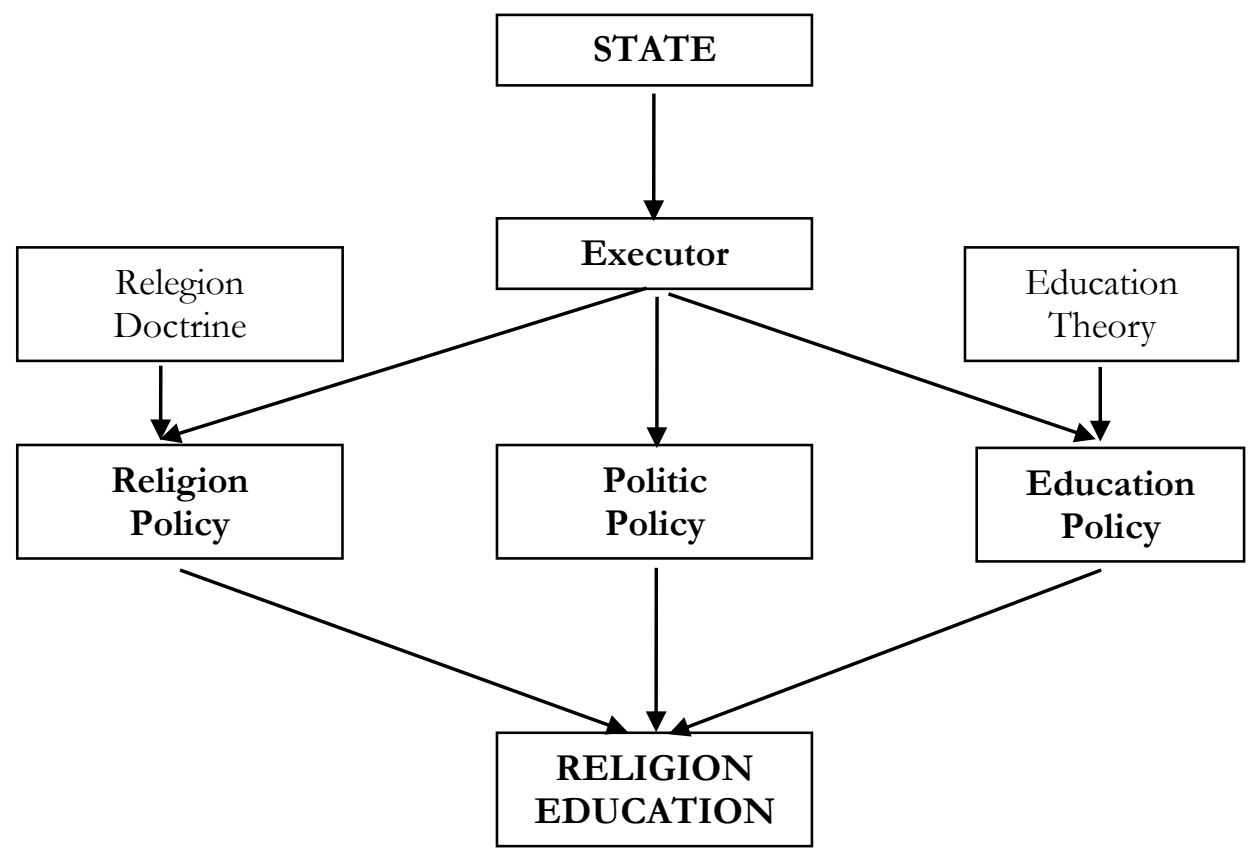

Islamic Religion Education with National Education System

This figure shows that an effort to develop Islamic Religion Education that is directed to National Education System including renew of curriculum, school empowerment as the central cultural value, establishment on National Education System based on decentralization, knowledge autonomy, and management. This development is supported by politic policy in order to improve the role of DPR/MPR and other parliament institutions by establishing its function and responsibility referring to authority principal and clear relationship among executive, legislative, and judiciary.

Islam ummah can play the real role in global society. The future must be reached by using education tools, thus, education must be accelerated to humans' future. That is why, actually, it is important to renew Islamic Religion Education system continually. The term long live education, obviously has been introduced by prophet Muhammad SAW "Get knowledge starting from a cradle until funeral" Thus, human beings must always learn how to learn. Learning is just like a recreation to the future (Fadjar, 1999: 38).

The renewal idea will not be implemented if there is no effort to change society's point of view from dycothomy to autonomy of education. The integration of education is followed by other isntitutions in responding globalization challenge and autonomization.

Basically, the efforts on Islamic Religion Education development have an objective to achieve an efficient and effective education as the process to reach 
the goal of National Education System. Therefore, there are two things that must be considered to recognize the efforts of Islamic Religion Education development: 1) Identifying all problems that constrain the implementation of Islamic Religion Education; 2) Formulating strategic and practical reformation that is applicable in the field.

In other words, the required condition from formulation program as an effort on Islamic Religion development in National Education System that must be established becomes the central point which must be noticed. In other words, it must be based on the reality occured at school and it must not pay attention much on slogan of Islamic Religion Education. Otherwise, it must show the real facts and valid result of research so that the effort of Islamic Religion Education can be intact, clear, and realistic.

Moreover, it requires a continually inovation to create a competitive superiority result of National Education System in Indonesia. To get a nation's dignity requires a competitive superiority in various field with supported from the learning result of Islamic Religion Education. Nowadays, it no longer counts on a cheap human resource to support and justify comparative and competitive superiority concept. In order to create a competitive superiority as an education outcome, Porter (1997: 54) suggests that it requires some efforts to charge Indonesian people for producing various competitive superiority as the education outcome including Islamic Religion Education that makes inovation become an important part of development of National Education System Without any significant inovation, Islamic Religion Education only produces graduates who do not have a moral and independent life guidance that will depend on others.

The problem of Islamic Religion Education appears on term of its development. In specific, its problem occurs on the definition and fucntion of Islamic Religion Education whether it is restricted on teaching pure religion knowledge only or it also teaches all aspects of life based on religion which refers to National Education System. It becomes serious because it determines the pattern of National Education System intactly. In addition, Islamic side suggests that Islamic education must be develop widely in Indonesia, however, non Islam side argues that it must be restricted to religion knowledge only. Finally, some strict provisions regarding Islamic Religion Education in National Education System are redommended by Badan Pekerja Komite Nasional Pusat (BPKNP). According to Hasan (2003: 48), those are as follows: 1) Islamic Religion Education subject at school must be delivers based on its schedule time at school; 2) Government pays the teachers; 3) At Elementary school, this subject is delivered started from fourth grade; 4) It is held once in a week; 5) All teachers are legalized by Ministry of Religion; 6) All teachers must acquire other general subject well; 7) Government provides religion education book; 8) Religion teachers get some trainings; 9) The quality of Islamic school must be improved; 10) Arabic lesson is no longer needed. 
Based on those recommendations, Islamic Religion Education is restricted on religion lesson at school started at fourth grade and is held once a week without Arabic lesson. In this recommendation, Islamic Religion Education at Islamic school does not have a special attention except provision number 9: the quality of Islamic school must be improved (Hasan, 2003: 50).

The main challenge faced by Islamic Religion Education experts and practitioners in the matter of integration Islamic school toward National Education System is the ommision of dycothomy between general and religion subjects. Knowledge must be viewed as a single identity that has developed historically. The development of knowledge historically shows that every human civilization including Islam civilization has given contribution to the knowledge itself.

The integration of Islamic school into National Education System has formed Act of National Education System in 1989 by government. Through the Act, Islamic school has changed its definition from religion school into general school based on Islam. This changing has an imprtant meaning since Islamic school does not get legitimation intactly as the part of National Education System. That is why Ministry of Religion as the institution that is responsible for Islamic school and other Islamic education institution has welcomed this Act enthusiastically Perubahan definisi ini penting artinya, karena dengan demikian berartimadrasah tidak hanya mendapat legitimasi sepenuhnya sebagai bagian dari Sistem Pendidikan Nasional (Hasan, 2003: 60).

However, this definition change influences to curriculum change as well. Since Islamic school is no longer religion school oriented, its curriculum must be dominated by general subjects although it still has a change to held religion subject at Islamic school based on its needs. In addition, since Islamic school is a kind of public school Islam oriented, Islamic values must be reflected in its curriculum especially in several subjects such as mathematics, history, chemistry, physics, and English. Thus, Islamic school's graduates are still different from other public school's graduates with the same quality.

In 1994, it was one of important periodes in developing Islamic school in Indonesia. At that time, Ministry of Religion had established new curriculum known as 1994 curriculum that required its implementation was under Ministry of Education. Different from the previous curriculum, Islmaic school contained $70 \%$ for general subjects and 30\% for Islamic Religion Education. In 1994 curriculum, Islamic school was made compulsory to give $100 \%$ for general subects as other general public school under Ministry of Education.

At glance, the main concern of 1994 curriculum was the abolishment of $30 \%$ religion subject since it was established in 1975 curriculum. However, if it was analyzed carefully, the abolition of religion subject not only omitted religion subject in Islamic school. Otherwise, it must be viewed as reformation of religion subject in Islamic school. In specific, Islamic study is no longer delivered in formal subject indepedently but it is integrated completely in other general 
subjects. This condition, at least, was supported by the effort of Ministry of Religion which organized guidance book with Islamic nuance for general subject teachers. It is expected that some general subjects given in Islamic school still consider Islamic values.

In 1994 curriculum, the dualism between religion and general subjects in Islamic school attempted to be ommitted. The islamic school is expected to held all integrated subjects together. However, Islamic education play a role in the context of national education system. It must be knowledgeable that based on institution, Islamic Religion Education lays in second position comparing with other subjects. For example, Islamic Religion Education major is less interested meanwhile other subjects are considered to have better future. Another fact can be shown in term of institution development. The department or school development under management or monitoring of Ministry of Religion is not the same with those which are supervised under Ministry of National Education. Worstly, it must adjust carefully with the condition of public schools. Even though Islamic Religion Education plays an important role in the context of national education, however, it must be admitted that the position of Islamic Religion Education is only a subsystem as a part of National Education System.

Some efforts on Islamic Religion Education development can be conducted by applying various learning methods: 1) Education based on model; 2) Education basedon tradition; 3) Education based on advice/story telling; 4) Education based on caring one to another; 5) Education based on reward and sanction.

The implementation on Islamic Religion Education development is an application of integration concept which means an integrated education process with an expectation for resulting an integrated output. Thus, the integration between Islamic Religion Education and other educations is along the way with the objective of National Education System. In particular, it results an output to be individual that has integrated akblâq and knowledge. The integration concept has three understandings:

1. The curriculum integration nowadays tends to be secular by implementing Islamic religion values to all subjects. For example, learning English has different perception with students from other school, as follows:

a. English subject is part of Islamic percept in which the main source comes from Allah SWT, so, every knowledge must be studied

b. English subject cannot be separated from the moslem obligation as the way to do religious service to Allah SWT. By learning it for exporing Islamic percept such as through literature, technology, information, and so on, Islam ummah will not be left behind in science and technology. 
2. The integration of cognitive, afective, psychomotor aspects in Islamic values that are directly and simultanously applied. For example, student learns how to do praying in Islamic Religion Education, he will apply praying together directly in a mosque. Another example, when he studies for counting numbers, he not only recognizes numbers but also learns that there are five Islamic, five times of praying, five fingers, and many others.

3. The integration between parents and school. Education process will fail if the development values are not synergy between school and parents at home. Thus, the roles of school, parents and society must be synergy and harmony to educate learners.

This Islamic Religion Education must be also corporated synergically between Ministry of Religion and Ministry foe Education and Culture so that they will seriously develop Islamic Religion Education. This make Islamic Religion Education become an integral part of National Education System. It means if now Islamic Religion Education is viewed as subsystem in the context of national education as suplementary subject at school, there will be a displacement role from suplementary to be substantial one. Indonesia is an archipelago known for its cultural and social diversity. With more than 200,000 islands, fewer than $30 \%$ of which are inhabited, and more than 300 different ethnicities all with their own cultural practices and traditions, Indonesia is the world's largest archipelago and the fourth most populated nation. Politically, although Indonesia is neither a secular nor a theocratic state, the government of the state has a significant power to control religious life through its apparatus. The latest Indonesian census shows that among its 220 million people, 88 percent are Muslim. Other religious groups include Protestants 5\%, Roman Catholics 3\%, Hindus 2\%, Buddhists 1\%, and others 1\% (Boyle and Sheen, 2001: 200-208).

Although Muslims are the majority, their distribution is not evenly spread. Some regions, mainly in eastern Indonesia, have almost equal numbers of Christians and Muslims, such as in Maluku, Manado, and many others. Some parts even have Christian majorities, such as in Nusa Tenggara Timur and Papua, and, of course, the island of Bali which is over 90\% Hindu. Responses of Islamic Education to the Religious Diversity in Indonesia Theologically, non Muslims were seen as the "other" by Muslims, based on the classical construction of Islamic teaching. The construction of fiqh and ilmu kalam on non-Muslims, for example, denotes them as musyrik or kafir. The problem is how Muslim, should deal with the "other" in their every day lives (Abdullah on http://aminabd.wordpress.com , 2010).

The Qur'an actually appreciates religious diversity on earth. Some Qur'anic verses clearly describe that Allah SWT does not intend to create people in a single identity, as stated in QS 10: 99 and 2: 256 below: And if thy Lord had pleased, all those who are in earth would have believed, all of them. Wilt thou 
then force men till they are believers? There is no compulsion in religion-the right way is indeed clearly distinc from error. So whoever disbelieves in the devil and believes in Allah, he indeed lays hold on the firmest handle which shall never break. And Allah is hearing knowing. The Qur'an even recognizes religious pluralism, as stated in QS 2: 62 Surely those who believe, and those who are Jews, and the Christians, and the Sabians, whoever believes in Allah and the Last Day and does good, they have their reward with their Lord, and there is no fear for them, nor shall they grieve. Although the Qur'an definitely describes the availability of religious pluralism, different interpretations of the verses appear among various Muslim groups, including Islamic education stake holders. A number of Muslim groups appreciates the verses and develops an inclusive, even pluralist, point of view; but some other groups interpret the verses differently and develop exclusive perspectives. Different interpretations would then lead them to have distinct points view and attitudes toward non-Muslims and the reality of religious diversity. Briefly speaking, considering the fact that Indonesia is full of diversity, religious and otherwise, each pillar of Islamic education has come up with different responses. Some of them definitely understand that diversity is part of sunnatullahb, so they develop educational systems curricula and content to teach their students in order to be ready to live together in a plural society (Abdullah on http:/ /aminabd.wordpress.com , 2010).

The Islamic education system in Indonesia can be divided into a number of groups. First is pesantren group, including those which carry out madrasah and those which still maintain non-grading system. This group consists of modern and traditional pesantren. Second is madrasah group consisting of both public and private madrasabs. Third is Sekolah Islam group, which is regarded as a genre of modern Islamic education system of urban Muslim community. Each group will be discussed separately with an attempt to connect them to each other (http://miftah19.wordpress.com).

The variety of Islamic educational institutions illustrates the dynamic of Islam in Indonesia, which has been searching for its form, especially in the context of modern and contemporary development. Despite the fact that there are pesantrens which embrace the spirit of fundamentalism, it is important to note that it is just a minor phenomenon. The majority of pesantrens in Indonesia are run with the spirit of moderate Islam. However, the campaign about the idea of moderate Islam which brings the values of democracy, tolerance, pluralism and civil society is not well-promoted (http://miftah19.wordpress.com ).

\section{CONCLUSION}

Based on discussion related on the effort on Islamic Religion Education implementation in National Education System, it can be drawn some conclusions, as follows: 1) in terminology, the objective of Islamic Religion Education can be defined as the achievement target by individual or group that 
implement Islamic Religion Education. In epistemology, actually, Islamic Religion Education has already had its own ideal vision and mission, i.e. "rabmatan lil âlamin". Moreover, the objective of education cannot be separated from human's life objective even though it is influenced by various cultures, view of life, and or other desires to have aqîdah (tarbiyah 'aqîdiyab), to form precious akhlâ (tarbiyah khuluqiyah), to form thoughtful person (tarbiyah fikriyah), to form healthy and forceful person (tarbiyah jismiyah), to form creative, initiative, antiphaty, and responsive (tarbiyah 'amaliyab); 2) the objective principle of Islamic Religion Education is based on al-Qur'ân, hadîts, Qaul al-Shahâbah, ijmâ', qiyâs, masâlih al-mursalah, shadżzu al-dzâri'ah, 'urf and istihsân. Besides, it is also supported by ijtihad executed by intellectual moslem which is based on aqidah, religion service and akhlaq. Furthermore, the application of Islamic Religion Education refers to six principles: (a) Universality of Islamic Religion Education, (b) Balancing, (c) Clarity, (d) Harmony, (e) Reality and applicable, (f) Dynamic and responsive toward alteration. Its role is to give contribution to the effort of potential development of its student as next generation who not only develops in intellectual field but also can realize their existence as insân kâmil based on his spiritual potential and skills. Thus, with his potential, he can color his life and his future to achieve happiness in the world and after life. Moreover, the objective function of education is to complete and to direct its objective as the foundation to reach other objectives, i.e., new or extansion objectives. Besides, it also gives value and characters of some efforts, provides criteria to evaluate education process and provides facilities that make education process possibly run well; 3) The characteristics of Islamic education include rabbâniyah,syâmilah, mutakâmilah, marhaliyah, murûnah, istimrâriyah, tanmawiyah, $\mathrm{Fa}$ rdi-yyah, tathbîiyah, hurriyah, infitâh, maslahah. To fulfil its objective functions, education objective must be formulated based on ideal faithful values that can raise human's dignity, i.e., an ideal value that becomes someone's mind construction and action to get directed goal; 4) The implementation on Islamic Religion Education development is an application of integration concept which means an integrated education process with an expectation for resulting an integrated output, Thus, the integration between Islamic Religion Education and other educations is along the way with the objective of National Education System. In particular, it results an output to be individual that has integrated akblâq and knowledge.

\section{REFERENCES}

Al-Abrasyi. 1961 al-Tarbiyah Fi al-Islâm, Kairo . al-Majlis al-A'la Li al-Syuun alIslamiyah.

Al-Rasyidin dan Samsul Nizar. 2005. Filsafat Pendidikan Islam, Pendekatan Historis, Teoritis dan Praktis. cet. Ke-2. Jakarta: PT Ciputat Press.

An-Nahlawi, Abdurrahman. 1989. Prinsip-prinsip dan Metoda Pendidikan Islam. Bandung. CV Diponegoro. 
Boyle, Kevin, and Juliet Sheen, (eds.). 2001. Freedom of Religious Belief: A Word Report. London \& New York: Routledge.

Dewey, J. 1916.Democracy and Education. London : Mac Millan

Fadjar, A. Malik. 1999. Reorientasi Pendidikan. Jakarta: Fajar Dunia.

Hamdani Ihsan dan Fuad Ihsan. 2007. Filsafat Pendidikan Islam.cetakan III. Bandung: CV. Pustaka Setia.

Hasan Basri, 2009. Filsafat Pendidikan Islam.Bandung: Pustaka Setia.

Hasan, M. Ali Mukti. 2003. Kapita Selekta Pendidikan Islam. Jakarta: CV Pedoman Ilmu Jaya.

Hitami, Munzir. 2004. Menggagas Kembali Pendidikan Islam. Yogyakarta: Infinite Press.

http://aminabd.wordpress.com/2010/06/01/religious-diversity-and-islamiceducation-in-indonesia/diunduh tanggal 29-7-2013.

http://miftah19.wordpress.com/2011/02/18/new-trend-of-islamic-educationin-indonesia/ diunduh tanggal 29-7-2013.

Lukens-Bull, Ronald. "Pendidikan Pesantren dan Harmoni Agama: Latar Belakang, Visi dan Misi." in Alef Theria Wasim, et. Al. (eds.). Harmoni Kehidupan Beragama: Problem, Praktik \& Pendidikan. Yogyakarta: Oasis Publisher, 2005.

Roqib, Moh. 2009. Ilmu Pendidikan Islam: Pengembangan Pendidikan Integratif di Sekolah, Keluarga dan Masyarakat. Yogyakarta.

Saifuddin, A.M. 1985. "Konsep Pendidikan Agama: Sebuab Pendekatan Integratif Inovatif," in Endang Basri Ananda, 70 Tabun Prof DR. H.M. Rasyidi. Jakarta: Harian Umum Pelita.

Sanaky, Hujair AH.2003. Paradigma Pendidikan Islam; Membangun Masyarakat Indonesia. Yogyakarta: Safiria Insania Press dan MSI.

Sholihin dan Rosyid Anwar, 2005. Akblak Tasawnf: Manusia, Etika, dan Makna Hidup, Bandung: Nuansa.

Undang-Undang Republik Indonesia. 2012. Sistem Pendidikan Nasional Beserta Penjelasannya. Jakarta: Grafika. 